\title{
Case Report and Review of the Literature
}

\section{Renal Lymphangiectasia as an Unusual Cause of Perirenal Collections: A Case Report and Literature Review}

\author{
Long Jiahuan Xanicia ${ }^{1 *}$ and Ng Kok Kit ${ }^{2}$ \\ ${ }^{\prime}$ Ministry of Health Holdings, Singapore \\ ${ }^{2}$ Department of Urology, Changi General Hospital, Singapore
}

\author{
ART ICLE INFO \\ Article history: \\ Received: 13 September, 2021 \\ Accepted: 29 September, 2021 \\ Published: 15 October, 2021

Keywords:
Renal lymphangiectasis
perirenal collections
kidney pathologies
marsupialisation
sclerotherapy

\begin{abstract}
A B S T R A C T
Renal lymphangiectasia (RLM) is a rare condition characterized by dilatation of perirenal, parapelvic or intrarenal lymphatics. We report an unusual case of bilateral RLM in a 20 -year-old Malay male who presented with 1 month duration of bilateral flank pain. Bedside ultrasound showed bilateral perinephric collections, which were further confirmed on computer tomography intravenous pyelogram (CT IVP). Other causes of perinephric collections were ruled out based on laboratory and radiological findings, and he was managed conservatively as for RLM with surveillance ultrasound kidneys at 3 to 6 monthly intervals.
\end{abstract}

\section{Introduction}

RLM is hypothesized to result from developmental malformation of the renal lymphatic tissues leading to obstruction and accumulation of lymph in the subcapsular region or hilum. Due to variable imaging findings, the differentials may be broad and diagnosis can be difficult. We aim to describe the clinical presentation, radiological findings, differentials and management of this condition using a case report and a review of the literature.

\section{Case Report}

A 20-year-old male presented to the emergency department for bilateral flank pain over 1 month. His past medical history includes L4/5 disc desiccation. Functionally, he is community ambulant and independent in activities of daily living. On examination, his abdomen was soft with tenderness over both flanks. Renal punch was equivocal bilaterally. Neurological examination of the lower limbs was unremarkable. His serum chemistry was as follows: white cell count $12.2 \times 10^{3} / \mu \mathrm{L}$, haemoglobin $14.4 \mathrm{~g} / \mathrm{dL}$, platelet count $210 \times 10^{9} / \mathrm{L}$, C-reactive protein $25.9 \mathrm{mg} / \mathrm{L}$, creatinine $143 \mu \mathrm{mol} / \mathrm{L}$. Urinalysis showed 4 red cells per high power field, 2 white cells per high power field, 0 epithelial cells. Urine culture showed no bacterial growth. Bedside ultrasound in the emergency department showed bilateral peripheral collections. CT IVP revealed bilateral symmetrical perinephric fluid collections measuring $12 \mathrm{~mm}$ thick with some free fluid within the retroperitoneum and pericolic gutters (Figure 1A). Hounsfield unit for the collections ranged $<10$. There was no urinary calculus, solid renal mass or hydronephrosis. The delayed excretory phase showed no contrast extravasation into the collections (Figure 1B), thereby ruling out the possibility of urinoma.

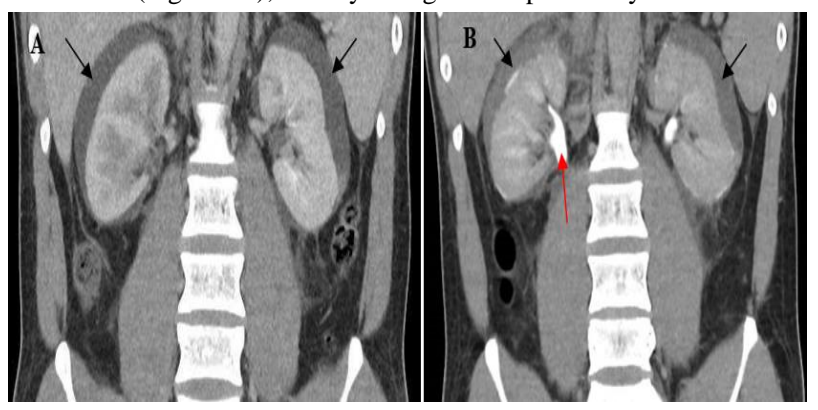

Figure 1: CT IVP A) medullary B) delayed/excretory phase. Red arrow showing ureter enhancement. $12 \mathrm{~mm}$ perinephric collections (black arrows), non-enhancing in excretory phase. 
Additional urine studies included $24 \mathrm{~h}$ urine protein of $0.22 \mathrm{~g} / \mathrm{day}$ and random urine protein of $0.11 \mathrm{~g} / \mathrm{L}$, hence ruling out proteinuric nephropathy. The patient was offered aspiration of collections for fluid analysis, which he declined and instead opted for conservative management with surveillance US kidneys every 3-6 months. At the 9month mark, there was an interval increase in the size of the left upper to mid pole collection to $6.3 \mathrm{~cm} \times 5.3 \mathrm{~cm} \times 2.0 \mathrm{~cm}$ (Figure 2) and the patient

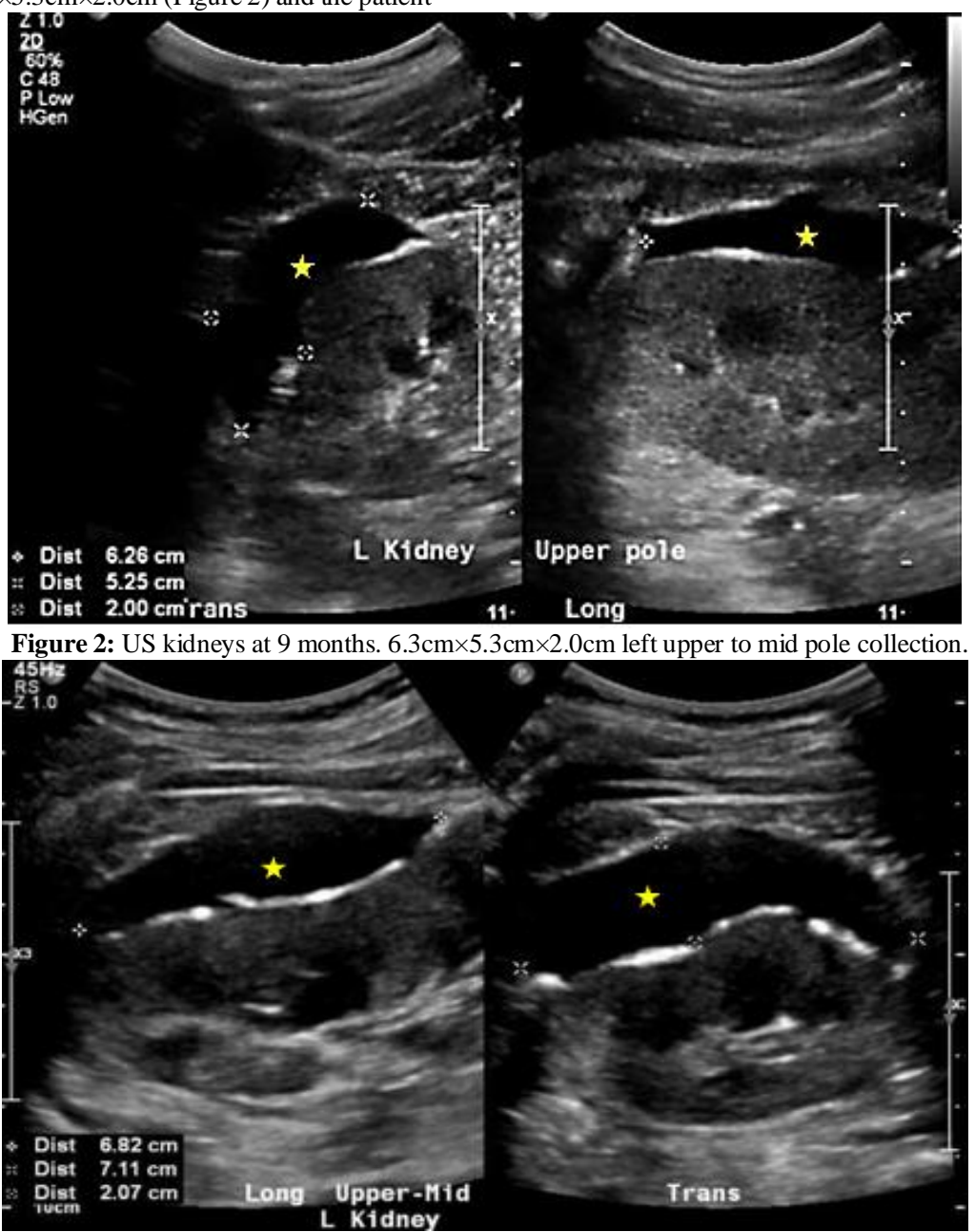

Figure 3: US kidneys at 15 months. $6.8 \mathrm{~cm} \times 7.1 \mathrm{~cm} \times 2.1 \mathrm{~cm}$ left upper to mid pole collection.

Table 1: Presentation, imaging findings and management of previous case reports.

\begin{tabular}{|c|c|c|c|c|c|c|c|}
\hline & Age & Sex & Comorbid & Presentation & Imaging findings & Complications & Management \\
\hline $\begin{array}{l}\text { Pandya VK et al. } \\
{[1]}\end{array}$ & 34 & $M$ & Nil & $\begin{array}{l}\text { Bilateral flank } \\
\text { pain }\end{array}$ & $\begin{array}{l}\text { US: anechoic PN collections } 33 \mathrm{~mm} \text { in } \\
\text { width } \\
\text { CT: PN collections of density } 0-10 \mathrm{HU}\end{array}$ & Nil & Conservative \\
\hline Chen $\mathrm{Z}$ et al. [2] & 34 & $F$ & Nil & $\begin{array}{l}\text { Fever, right flank } \\
\text { pain }\end{array}$ & $\begin{array}{l}\text { US: dilatation of right PC space and right } \\
\text { PN collection } \\
\text { CT: bilateral polycysts in the renal sinus } \\
\text { and right PN collection }\end{array}$ & Nil & $\begin{array}{l}\text { Emergency } \\
\text { exploratory surgery, } \\
\text { followed by } \\
\text { nephrectomy for } \\
\text { uncontrolled hilar } \\
\text { leakage }\end{array}$ \\
\hline $\begin{array}{l}\text { Choudhury S et } \\
\text { al. [3] }\end{array}$ & 16 & M & Nil & $\begin{array}{l}\text { Abdominal } \\
\text { distension, pain }\end{array}$ & $\begin{array}{l}\text { CT: subcapsular PN collections without } \\
\text { PC communication, compression of PC } \\
\text { system }\end{array}$ & HTN & $\begin{array}{l}\text { Percutaneous drainage } \\
\text { and sclerotherapy }\end{array}$ \\
\hline
\end{tabular}

was re-offered aspiration, which he declined as he was asymptomatic. At the 15-month mark, there was a further increase in the size of the above-mentioned collection to $6.8 \mathrm{~cm} \times 7.1 \mathrm{~cm} \times 2.1 \mathrm{~cm}$ (Figure 3). The latest US kidneys at the 21-month mark showed a reduction in size to $7.3 \mathrm{~cm} \times 5.0 \mathrm{~cm} \times 1.9 \mathrm{~cm}$. The patient remained asymptomatic throughout his course of follow-up consults. 


\begin{tabular}{|c|c|c|c|c|c|c|c|}
\hline $\begin{array}{l}\text { Ashraf K etal. } \\
{[4]}\end{array}$ & 23 & $\mathrm{~F}$ & $\begin{array}{l}\text { Para } \\
\text { umbilical } \\
\text { hernia }\end{array}$ & $\begin{array}{l}\text { Abdominal } \\
\text { distension and } \\
\text { pain } \times 1 / 12\end{array}$ & $\begin{array}{l}\text { US: ascites and bilateral dilatation of PC } \\
\text { system } \\
\text { CT abdomen: bilateral renal sinus } \\
\text { collections } 15 \mathrm{HU}\end{array}$ & HTN, ascites & $\begin{array}{l}\text { Conservative with } \\
\text { diuretics and } \\
\text { antihypertensive }\end{array}$ \\
\hline Koc NS et al. [5] & 30 & $\mathrm{M}$ & Young HTN & $\begin{array}{l}\text { Diagnosed as } \\
\text { ADPKD at age } \\
20 \text { based on US } \\
\text { kidney findings > } \\
\text { MRI done 10y } \\
\text { later to calculate } \\
\text { kidney volume } \\
\text { for tolvaptan } \\
\text { treatment }\end{array}$ & $\begin{array}{l}\text { MRI kidneys: multiple peripherally } \\
\text { located cysts hyperintense on T2WI and } \\
\text { hypointense on T1WI }\end{array}$ & HTN & Conservative \\
\hline $\begin{array}{l}\text { Umapathy S et } \\
\text { al. [6] }\end{array}$ & 49 & $M$ & Nil & $\begin{array}{l}\text { Left loin pain } \\
\mathrm{x} 1 / 12\end{array}$ & $\begin{array}{l}\text { CT: } 9 \text { x } 6.5 \text { x } 6.2 \mathrm{~cm} \text { cystic lesion in left } \\
\text { renal sinus distorting the PC system with } \\
\text { PN fat stranding }\end{array}$ & $\begin{array}{l}\text { Renal vein } \\
\text { thrombosis }\end{array}$ & Conservative \\
\hline $\begin{array}{l}\text { Al-Dofri et al. } \\
{[7]}\end{array}$ & 22 & $\mathrm{M}$ & Nil & $\begin{array}{l}\text { Abdominal } \\
\text { distension and } \\
\text { pain, dyspnea } \\
\text { x6/12 }\end{array}$ & $\begin{array}{l}\mathrm{CT} \text { : renal sinus cysts } 3 \mathrm{HU} ; \mathrm{PN} \text { collection } \\
2 \mathrm{HU} \text {; right pleural effusion and ascites } \\
3 \mathrm{HU}\end{array}$ & $\begin{array}{l}\text { Pleural } \\
\text { effusion, } \\
\text { ascites }\end{array}$ & $\begin{array}{l}\text { Conservative with } \\
\text { diuretics }\end{array}$ \\
\hline $\begin{array}{l}\text { Pianezza et al. } \\
{[8]}\end{array}$ & 52 & $M$ & $\begin{array}{l}\text { Pancreatic } \\
\text { psuedocyst }\end{array}$ & $\begin{array}{l}\text { Bilateral flank } \\
\text { pain and gross } \\
\text { haematuria }\end{array}$ & $\begin{array}{l}\text { US: PN hypoechoic lesions with thin } \\
\text { septations, loss of corticomedullary } \\
\text { differentiation } \\
\text { CT: multilocated pararenal cystic lesion, } \\
\text { density of 0-10 HU, atrophic kidney } \\
\text { MRI kidneys: non enhancing cystic lesion } \\
\text { on T1WI; increased cortical and } \\
\text { decreased medullary intensity on T2WI }\end{array}$ & $\begin{array}{l}\text { Gross } \\
\text { haematuria }\end{array}$ & Conservative \\
\hline $\begin{array}{l}\text { Blanc M. et al. } \\
{[9]}\end{array}$ & 58 & $\mathrm{M}$ & $\begin{array}{l}\text { Newly } \\
\text { diagnosed } \\
\text { HTN }\end{array}$ & $\begin{array}{l}\text { Fatigue } \\
\text { Hb } 213 \mathrm{~g} / \mathrm{L} \\
\text { Hct } 0.63\end{array}$ & $\begin{array}{l}\text { US: unilateral right PN anechoic } \\
\text { collection with multiple septa } \\
\text { CT: water-density right PN collection } \\
\text { with lobulated contours extending to the } \\
\text { renal hilum with renal parenchymal } \\
\text { compression } \\
\text { Renal scintigraphy MAG-3: renal } \\
\text { function of } 47 \% \text { on the right kidney and } \\
53 \% \text { on the left }\end{array}$ & $\begin{array}{l}\text { HTN, } \\
\text { polycythemia }\end{array}$ & $\begin{array}{l}\text { Percutaneous drainage } \\
\text { followed by } \\
\text { laparoscopic bilateral } \\
\text { marsupialisation }\end{array}$ \\
\hline Ali K. et al. [10] & 50 & $\mathrm{~F}$ & $\begin{array}{l}\text { Lupus } \\
\text { nephritis s/p } \\
3 \text { renal } \\
\text { transplants }\end{array}$ & $\begin{array}{l}\text { Right lower } \\
\text { quadrant pain } 13 \\
\text { months following } \\
\text { last renal } \\
\text { transplant }\end{array}$ & $\begin{array}{l}\text { US: multi-septated thin-walled fluid } \\
\text { collection in the hilum separate from } \\
\text { collecting system } \\
\text { MRI kidney: non enhancing peripelvic } \\
\text { multiseptated collection hypointense on } \\
\text { T1 hyperintense on } \mathrm{T} 2\end{array}$ & $\begin{array}{l}\text { Worsening } \\
\text { kidney function } \\
\text { post-transplant }\end{array}$ & $\begin{array}{l}\text { Percutaneous drainage } \\
\text { initially and then wide } \\
\text { peritoneal fenestration } \\
\text { and omentoplasty }\end{array}$ \\
\hline $\begin{array}{l}\text { Hamroun A. et } \\
\text { al. }[11]\end{array}$ & 34 & $M$ & $\begin{array}{l}\text { ESRD 2' } \\
\text { FSGS s/p } \\
\text { renal } \\
\text { transplant }\end{array}$ & $\begin{array}{l}\text { Refractory ascites } \\
10 \text { years } \\
\text { following kidney } \\
\text { transplant }\end{array}$ & $\begin{array}{l}\text { MR urography: multiple plurilobular fluid } \\
\text { collections located at parapyelic, } \\
\text { juxtacapsular, and perihilar regions }\end{array}$ & $\begin{array}{l}\text { Inguinoscrotal } \\
\text { hydrocele, } \\
\text { bladder } \\
\text { compression } \\
\text { from mass } \\
\text { effect }\end{array}$ & $\begin{array}{l}\text { Conversion to } \\
\text { mammalian target of } \\
\text { rapamycin (mTOR) } \\
\text { inhibitor } \\
\text { Hydrocele managed } \\
\text { conservatively }\end{array}$ \\
\hline
\end{tabular}




\begin{tabular}{|l|l|l|l|l|l|l|l|}
\hline & 35 & M & $\begin{array}{l}\text { ESRD 2' } \\
\text { childhood } \\
\text { HUS s/p } \\
\text { renal } \\
\text { transplant }\end{array}$ & $\begin{array}{l}\text { Chronic pelvic } \\
\text { pain with LUTS } \\
\text { for 8 years }\end{array}$ & $\begin{array}{l}\text { US: nephromegaly (16 } \\
\text { cm), multiple peripyelic cysts, } \\
\text { perihepatic, and perisplenic ascites }\end{array}$ & $\begin{array}{l}\text { Bladder } \\
\text { compression } \\
\text { from mass } \\
\text { effect resulting } \\
\text { in LUTS }\end{array}$ & $\begin{array}{l}\text { Mofetil } \\
\text { mycophenolate was } \\
\text { switched to mTORi } \\
\text { MR urography: nephromegaly (729cc) } \\
\text { pericapsular collection and edematous } \\
\text { infiltration of perirenal fat }\end{array}$ \\
\hline $\begin{array}{l}\text { Dawidek M. T. } \\
\text { et al. }[12]\end{array}$ & 55 & F & $\begin{array}{l}\text { ESRD 2' } \\
\text { microscopic } \\
\text { polyangitis } \\
\text { sp renal } \\
\text { transplant }\end{array}$ & $\begin{array}{l}\text { New onset ascites } \\
\text { 4 years post } \\
\text { transplant }\end{array}$ & $\begin{array}{l}\text { US kidneys: loss of corticomedullary } \\
\text { differentiation with subcapsular fluid } \\
\text { densities }\end{array}$ & $\begin{array}{l}\text { Ascites, } \\
\text { umbilical and } \\
\text { laparoscopic } \\
\text { port incisional } \\
\text { hernias }\end{array}$ & $\begin{array}{l}\text { Allograft } \\
\text { nephrectomy with } \\
\text { concurrent hernia } \\
\text { repair }\end{array}$ \\
\hline
\end{tabular}

PN: Perinephric; PC: Pelvicalyceal; HU: Hounsfield Units; HTN: Hypertension; Hb: Haemoglobin; Hct: Haematocrit; ESRD: End Stage Renal Disease; FSGS: Focal and Segmental Glomerulosclerosis; HUS: Hemolytic Uraemic Syndrome; LUTS: Lower Urinary Tract Symptoms

\section{Discussion}

Renal lymphangiectasia (RLM) is an uncommon cause of perirenal and parapelvic collections. It can present unilaterally or bilaterally and has no age or gender predilection [6]. The familial nature of the disease has been reported [13]. Its pathogenesis is hypothesized to result from developmental malformation of the renal lymphatic tissues. The lymphatic drainage of the kidney, renal capsule, and the perinephric region intercommunicate through lymphatic trunks within the renal sinus [6]. These lymphatics drain into the paraaortic, paracaval, and interaortocaval lymph nodes [6]. In RLM, there is impairment in the drainage of larger renal sinus lymphatic trunks with resultant dilatation of peripelvic and perinephric and intrarenal lymphatics [6]. It is usually asymptomatic and incidentally diagnosed on radiological imaging as perinephric or parapelvic fluid collections. When symptomatic, it may be associated with pain, abdominal distension, hematuria, hypertension, and less commonly deterioration of renal function, renal vein thrombosis, polycythemia and pleural effusion (see Table 1 for a summary of different presentations of RLM from previous case reports).

Differentials commonly include but are not limited to $[5,6,8,9]$ :

$\begin{aligned} \text { i. } & \text { Polycystic kidneys } \\ \text { ii. } & \text { Hydronephrosis } \\ \text { iii. } & \text { Urinoma } \\ \text { iv. } & \text { Cystic nephroma } \\ \text { v. } & \text { Lymphoma } \\ \text { vi. } & \text { Nephroblastomatosis }\end{aligned}$

These conditions may be difficult to differentiate from RLM using a single imaging modality, and hence the need for correlation of clinical history, biochemical parameters and additional imaging modalities beyond ultrasound (Table 2).

Table 2: Summary of differentials for RLM and their imaging findings.

\begin{tabular}{|c|c|c|c|}
\hline Differentials & US findings & Contrasted CT findings & MRI findings \\
\hline Polycystic kidneys & $\begin{array}{l}\text { Massive enlarged kidneys } \\
\text { Multiple anechoic cysts of varying sizes } \\
\text { Distortion of normal renal parenchyma }\end{array}$ & $\begin{array}{l}\text { Cysts with fluid attenuation can be found in } \\
\text { the cortex/hilar space/subcapsular space } \\
\text { No enhancement }\end{array}$ & $\begin{array}{l}\text { MRI rarely indicated, unless for workup for } \\
\text { complicated/complex cysts with the need to } \\
\text { rule out malignant component on the } \\
\text { background of impaired renal function }\end{array}$ \\
\hline Hydronephrosis & $\begin{array}{l}\text { Dilation (not displacement) of pelvis and } \\
\text { calyces }\end{array}$ & $\begin{array}{l}\text { Opacification of collecting system in } \\
\text { delayed phase from the filling of contrast } \\
\text { Source of obstruction identifiable at renal } \\
\text { pelvis/ureter/vesicoureteric junction/ } \\
\text { bladder }\end{array}$ & MRI rarely indicated \\
\hline Urinoma & $\begin{array}{l}\text { Thin walled anechoic collection } \\
\text { contouring any portion of the renal tracts }\end{array}$ & $\begin{array}{l}\text { Urinary leakage in delayed phase due to } \\
\text { direct contrast extravasation from the } \\
\text { urinary tract }\end{array}$ & $\begin{array}{l}\text { T1: hypointense } \\
\text { T2: hyperintense }\end{array}$ \\
\hline $\begin{array}{l}\text { Multilocular cystic } \\
\text { nephroma }\end{array}$ & $\begin{array}{l}\text { Multilocular anechoic mass originating } \\
\text { from kidney -- claw or beak-shape of } \\
\text { adjacent renal parenchyma } \\
\text { Septal vascularity }\end{array}$ & $\begin{array}{l}\text { Encapsulated well-circumscribed mass with } \\
\text { near-water HU } \\
\text { Enhancing septa and no excretion of } \\
\text { contrast agent into the cyst } \\
\text { No nodular or solid enhancement }\end{array}$ & $\begin{array}{l}\text { T1: variable signal, depending on the protein } \\
\text { or blood products of the cysts } \\
\text { T2: hyperintense }\end{array}$ \\
\hline
\end{tabular}




\begin{tabular}{|l|l|l|l|}
\hline Lymphoma & Internal vascularity of mass & $\begin{array}{l}\text { Soft tissue attenuation with enhancement } \\
\text { Associated with: splenomegaly, } \\
\text { retroperitoneal lymphadenopathy }\end{array}$ & T2: iso- or hyperintense \\
\hline Nephroblastomatosis & Enlarged diffusely hypoechoeic kidneys & $\begin{array}{l}\text { Poorly enhancing soft tissue lesion with } \\
\text { adjacent normally enhancing renal } \\
\text { parenchyma }\end{array}$ & T1: low-signal-intensity nodules \\
\hline
\end{tabular}

The features of RLM on US and CT depend on the site and extent of lymphatic obstruction (see Table 1 for variations of radiological findings of RLM from previous case reports). When mainly smaller intrarenal lymphatics are blocked, diffuse enlargement of kidneys may be seen without cystic spaces [4]. Loss of cortico-medullary differentiation may be seen in more chronic cases $[4,8]$. On CT, collections may be accompanied by the presence of septa. The attenuation of these collections lies in the range of fluid [1, 7-9]. Imaging findings of perirenal and parapelvic involvement sparing the renal parenchyma are highly suggestive of RLM as opposed to other conditions involving pathology of the renal parenchyma. MRI is not commonly performed as US and contrast-enhanced CT often suffice in ruling out differentials, and any value of performing MRI would be academic. MRI typically shows hyperintense collections on $\mathrm{T} 2 \mathrm{~W}$ images with reversal of corticomedullary intensity due to fewer small lymphatics in the midcortex and absence of lymphatics in the medulla $[5,8,14]$.

Asymptomatic collections can be managed conservatively. Diuretics can be used to control ascites and anti-hypertensive medication is used to control hypertension when present $[4,7]$. When collections are very large and causing pressure symptoms, percutaneous drainage may be performed and fluid analysis typically shows chylous fluid with lymphocytic predominance with small amounts of fat globules, proteins and high renin levels in the fluid $[3,4,6,9,14]$. Histological examination of fluid may also play an important role if there is a suspicion of malignancy. RLM is positive for lymphatic endothelial immunomarkers such as D2-40 and is characterized by cortical dilated endothelial-lined spaces without glomerular or tubular abnormalities [10]. Percutaneous drainage, despite being easy to perform, is often only a temporary measure and cannot be considered a definitive solution because it is inevitably followed by recurrence and might also be difficult to achieve complete drainage in the presence of septations [2, 3, 9, 14]. Definitive surgical interventions reported in the literature include marsupialisation, sclerotherapy and nephrectomy (Table 1) [2, 3, 9, 15, 16]. Marsupialisation has been reported to be complicated by extensive hemorrhage mandating nephrectomy $[14,16]$. Possible reasoning would be that lesions in the renal hilum can be difficult to isolate and surgical manipulation at the hilum can lead to unintentional nicking of hilar vessels. Sclerotherapy in conjunction with percutaneous drainage can conversely avoid such complications. Povidone-iodine can be used as a sclerosant as it is homogeneously distributed, long-acting and minimally irritative to the urinary tract, which prevents stricture formation $[3,15]$. Nephrectomy is not commonly performed and is reserved for recurrent collections or uncontrolled intraoperative bleeding [4, 17]. Existing literature on RLM mainly describe the condition in native kidneys, and it is rare in the context of renal transplant. The diagnosis of RLM should be considered in renal transplant patients with ascites after all other sources have been ruled out [10-12]. Renal lymphangiectasia with high output ascites may ultimately require treatment with allograft nephrectomy [12].

\section{Conclusion}

In conclusion, we present a case of renal lymphangiectasia, which was managed conservatively with surveillance imaging as the patient was asymptomatic. Despite interval increase in the size of perinephric collections from the 9-month to 15 -month mark, the patient did not undergo any invasive intervention as he was asymptomatic, and subsequent reduction in the size of collections was noted in the most recent US kidneys. Awareness of this condition will be helpful in differentiating it from other renal cystic diseases and other causes of perirenal collections, which is key in guiding appropriate management and avoiding over-investigating and subjecting the patient to unnecessary procedures. Nevertheless, surveillance scans and follow-up are recommended in all patients due to the risk of complications such as renal failure and hypertension, which might only present at a later stage. Percutaneous drainage is the first line of management in less severe symptomatic cases but has a lower success rate in larger lesions with multiseptation. Marsupialisation, sclerotherapy and nephrectomy are reserved for more symptomatic cases associated with larger cysts or multiple recurrences. Lack of sufficient data in literature makes a comparison in functional outcomes by different surgical techniques difficult.

\section{Conflicts of Interest}

None.

\section{REFERENCES}

1. Pandya VK, Shah MK, Gandhi SP, Patel HV (2016) Bilateral Renal Lymphangiectasia. J Clin Diagn Res 10: TD01-TD02. [Crossref]

2. Chen Z, Qi L, Tang Z, Hu Z, Fan B (2009) Renal lymphangiectasia. Scand J Urol Nephrol 43: 428-430. [Crossref]

3. Choudhury S, Sridhar K, Pal DK (2017) Renal lymphangiectasia treated with percutaneous drainage and sclerotherapy. Int $J$ Adolesc Med Health 31. [Crossref]

4. Ashraf K, Raza SS, Ashraf O, Memon W, Memon A et al. (2007) Renal lymphangiectasia. Br J Radiol 80: e117-e118. [Crossref]

5. Koc NS, Yilmaz SR, Karcaaltincaba M, Yildirim T, Erdem Y (2021) Renal Lymphangiomatosis Mimicking Polycystic Kidney Disease In An Adult, A Case Report and Literature Review. Iran J Kidney Dis 1: 61-63. [Crossref]

6. Umapathy $\mathrm{S}$, Alavandar E, Renganathan $\mathrm{R}$, Thambidurai $\mathrm{S}$, Arunachalam VK (2020) Renal Lymphangiectasia: An Unusual 
Mimicker of Cystic Renal Disease - A Case Series and Literature Review. Cureus 12: e10849. [Crossref]

7. Al Dofri SAA (2009) Renal lymphangiectasia presented by pleural effusion and ascites. J Radiol Case Rep 3: 5-10. [Crossref]

8. Pianezza ML, Mokhtassi A, Wu L, D'A Honey RJ (2006) Case report: renal lymphangiectasia. Can J Urol 13: 3204-3207. [Crossref]

9. Blanc M, Schmutz G, Belzile F, Sabbagh R (2014) Renal lymphangiectasia presenting with hypertension and polycythemia. Can Urol Assoc J 8: E163-E166. [Crossref]

10. Kord A, Benedetti E, Bui JT (2020) Posttransplant Intrarenal Lymphangiectasia. Case Rep Transplant 2020: 8824833. [Crossref]

11. Hamroun A, Puech P, Maanaoui M, Bouyé S, Hazzan M et al. (2021) Renal Lymphangiectasia, a Rare Complication After Kidney Transplantation. Kidney Int Rep 6: 1475-1479. [Crossref]

12. Dawidek MT, Aquil S, Alogaili R, Gabril M, Moussa M et al. (2020) Renal Lymphangiectasia in the Transplanted Kidney: Case Series and Literature Review. Transplantation 104: 172-175. [Crossref]
13. Antonopoulos P, Charalampopoulos G, Constantinidis F, Tavernaraki K, Skolarikos A (2010) Familial renal retroperitoneal lymphangiomatosis: personal experience and review of literature. $J B R$ BTR 93: 258-261. [Crossref]

14. Wadhwa P, Kumar A, Sharma S, Dogra PN, Hemal AK (2007) Renal lymphangiomatosis: imaging and management of a rare renal anomaly. Int Urol Nephrol 39: 365-368. [Crossref]

15. Valerio M, Meuwly JY, Tawadros C, Jichlinski P (2012) Percutaneous drainage and sclerotherapy as definitive treatment of renal lymphangiomatosis. Can Urol Assoc J 6: E3-E7. [Crossref]

16. Meyyappan RM, Ravikumar S, Gopinath M (2013) Laparoscopic management in a rare case of bilateral perirenal lymphangiomatosis. Indian J Urol 29: 73-74. [Crossref]

17. Wani NA, Kosar T, Gojwari T, Qureshi UA (2011) Perinephric fluid collections due to renal lymphangiectasia. Am J Kidney Dis 57: 347351. [Crossref] 